\title{
Challenges of Megaproject Management of Education in Contemporary Russia
}

\author{
Inga $K$. Polyanskaya ${ }^{1 *}$, Lyudmila $V$. Kuznetsova ${ }^{1}$, Liliya $S$. Brusentsova ${ }^{1}$, and Evgeniy $V$. \\ Kozhevnikov $^{1}$ \\ ${ }^{1}$ Financial University under the Government of the Russian Federation, Moscow, Russia
}

\begin{abstract}
This article discusses the theoretical foundations of megaproject management. Based on consideration of education management in contemporary Russia, the issues of implementing megaproject management are identified. The purpose of the study is to determine the problems and opportunities of megaproject management in education. The project classification is made on various grounds, and information on one of the key Russian national projects, namely, Education is provided. The article considers the relationship of megaprojects with the government's economic policy, as well as the ratio of expenditures as a percentage of GDP in the most important sectors of society's development. The use of logical and statistical methods allowed concluding the prevalence of large-scale projects in the Russian economy regardless of their effectiveness. The reasons for the inefficiency of megaproject management are quite numerous, including methodological problems, features of the institutional environment, and the emerging centralized model of economic management in Russia.
\end{abstract}

\section{Introduction}

Government project management is a topic that deserves the close attention of theorists and practitioners. Large government projects can contribute to economic development, but they can also cause stagnation.

Education develops human capital which is the most important factor in economic growth. In this regard, the issue of project management effectiveness in education remains relevant and debatable.

Despite the increased scope of research on megaproject management, the continuous changes and unforeseen events at the global and regional levels make this topic inexhaustible.

The purpose of the present research is to study the issues of megaproject management, including megaproject management of education in contemporary Russia. This will make it possible to advance the understanding of the specifics in the management of government projects.

The research aims to study the theory and practice of megaproject management and identify the causes of the inefficiency of megaproject management.

\footnotetext{
* Corresponding author: polyanskaya.ik@mail.ru
} 


\section{Methods}

The main research method is a review and analysis of the literature on megaproject management issues. Theoretical research methods include analysis, synthesis, comparison, abstraction, concretization, generalization, formalization, as well as analogy and modeling which allowed building a logical scheme of the research project. The authors proceed from the typology of projects to the megaproject management problems, and, further, from the institutional analysis of the role of national megaprojects in the economic policy of the Russian government to finding out the problems of implementing the national Education project.

\section{Results}

1. Over the past decade, interest in project management has grown significantly [1]. Researchers and practitioners pay special attention to large government projects called megaprojects. Of all the known project types, megaprojects are the least studied and most exposed to risks.

2. The problems of megaproject management concern complexity in design and control. Many government projects and programs are extended for years, do not reach their goals, and suddenly are terminated at the planning or implementation stage [2]. The effectiveness of the evaluation methods to predict the success of megaprojects is considered in [3].

Megaprojects with state participation are likely to be corrupt. Corruption increases the project cost and time, as well as reduces the benefits [4].

3. Serious problems may be caused by the risk of replacing the competitive mechanism of innovative development and change management. Megaprojects in centralized management models of the national economy limit the independence of organizations in decision-making, create conditions incompatible with the system of "creative destruction", and limit the entrepreneurial potential of the business. More details about supporting and promoting innovation in UK megaprojects can be found in [5].

4. Megaprojects, developed within the framework of the input-output macroeconomic functional model, do not take into account the quality of the institutional environment. The problems associated with megaprojects go beyond technical problems, and thus they should be considered as projects embedded in a complex institutional framework [6]. The study of the institutional environment, i.e. the conditions for the implementation of megaprojects has great theoretical and practical significance.

5. The emerging model of megaproject management in contemporary Russia is based on the concept of the effectiveness of direct-centralized (administrative) management of the country's economic development. The state determines the goals and objectives. Financing is carried out through the centralized distribution of financial resources in certain areas of socio-economic development.

6. The problems of implementing the national Education project are caused by a combination of factors, such as the features of the institutional environment, i.e. the quality of economic, political, social and legal institutions; insufficient knowledge of the megaproject management mechanism; unfavorable world conditions; unfavorable investment climate and a decrease in business activity; a decrease in demand for educational services; mistakes of national project implementers, as well as unforeseen events.

\section{Discussion}


As an independent scientific and practical activity, Project Management (PM) began emerging in the 2nd half of the 20th century. A significant contribution to the PM development was made by specialists of the Project Management Institute (PMI), established in 1969 in the USA. In the 6th edition of PMBOK (Project Management Body of Knowledge), a project is determined as a temporary enterprise designed to create unique products, services, or results.

Project typology is based on a variety of criteria, such as project goal, the scope of activity, time and territorial restrictions, amount of resources used, project scope, management methods, and others. The most developed areas of PM are technical and economic issues. Diethelm G. identifies the business, social, military, public, personal, and international public projects [7]. D. Locke distinguishes engineering and construction, construction, petrochemical, mining and quarry, industrial, management, and research projects [8].

V. Voropaev notes that the megaprojects and multiprojects are the most complex: "... the features of Russian megaprojects are related to both the essence of the very projects and their environment, as well as to the complex relationships of external and internal factors" [9].

G. Nano defines megaprojects as meta-organizations, i.e. a network of legally independent entities cooperating within a certain goal at the system level [10].

According to $\mathrm{Yu}$. Zidan et al., the researchers do not give a clear-cut definition of megaproject. The criteria for megaprojects include a high cost - more than one billion dollars, scale, and duration, such as the construction of a railway tunnel under the English Channel, the holding of the Olympic Games, and others [11].

Large-scale projects in Russia began to be implemented in the 1930s, i.e. during the period of socialist industrialization. Project management in contemporary Russia has begun with the adoption in 2000 of the "Program for the Socio-Economic Development of the Russian Federation for the Period 2000-2010". Later, federal target programs, concepts, and development strategies were approved.

To ensure the potential for economic growth, the national Education project solves the human capital development problem. According to the World Bank report, human capital accounts for the largest share of wealth in Russia equal to $46 \%$. Produced capital equals to $33 \%$, natural capital - to $20 \%$, and net foreign assets - to $1 \%$. In the wealth structure of the OECD (Organisation for Economic Cooperation and Development) countries, human capital is on average $70 \%$, produced capital $-28 \%$, natural capital $-3 \%$, and net foreign assets minus 1\%. From 2000 to 2017, in Russia, the indicator of human capital per capita has increased by $80 \%$ while the indicator of total wealth per capita increased by $76 \%$. In terms of the growth rate of human capital per capita, Russia is ahead of the OECD countries and countries that export raw materials. But since 2014, the indicator of total wealth per capita started decreasing. This is due to the lack of growth in human capital and a serious decline in the value of oil and gas due to the deterioration of the situation on world markets [12].

Decree of the President of the Russian Federation dated May 7, 2018 No. 204 "On National Goals and Strategic Objectives of the Russian Federation through to 2024" defined goals and objectives in 12 strategic areas.

Among the key goals of the national Education project is to ensure the global competitiveness of Russian education and to enter into the top 10 countries in the world for the quality of general education [13]. The national Education project involves the implementation of four main development paths in the education system: updating its content, creating a contemporary infrastructure, training professional personnel, retraining, and advanced training, and creating effective management mechanisms. It is assumed that these goals can be achieved through coordinated actions of the educational organization management and control of officials at all management levels, ensuring continuity and an integrated approach in working with various categories of personnel [14]. 
As practice has shown, long-term megaprojects implemented in Russia since 2000 have not yet been completed. The reforms planned in the "Program for the Socio-Economic Development of the Russian Federation for the Period 2000-2010" were suspended. Targets approved in the "Concept of socio-economic development of Russia until 2020" in 2008 were not achieved. In 2019, the proportion of oil and gas revenues in the total volume of federal budget revenues decreased to $39.3 \%$. The growth rate of the economy slowed to $1.3 \%$ compared to $2.5 \%$ in 2018 . [15].

In 2019, total federal budget expenditures amounted to 18,214.5 billion rubles, including spending for education -826.5 ; healthcare -713.0 ; national economy $-2,827.1$; national defense - 2,997.4; national security and law enforcement - 2,883.2 [16].

Russia spends about $3.5 \%$ of GDP on education, ranking 29th among 33 OECD countries. In 2019, in terms of state funding for science, Russia lagged behind the USA by 33 times, China - by 22 times, Germany - by 8 times, and South Korea - by 4 times [17].

The target indicators of the national Education project were set without consideration of the real capabilities of the entities and without having a transparent methodology for detailing the values. Thus, the implementation of the May decrees on raising salaries for education employees from regional budgets has led to a growing differentiation in remuneration. Thus, teachers' salaries by regions ranged from 3-4 to 12-14 thousand rubles. The further measures for tightening control over the implementation of these decrees were focused on optimization of the staff schedule of educational organizations to reduce staff in the education sector that led to an increase in the volume and labor intensity of remained staff members [18].

National project passports and progress reports do not contain complete and reliable information about risks. There is no comprehensive system for monitoring and controlling the implementation of national projects. As of December 28, 2019, the level of expenditure execution on national projects was $88.1 \%$.

A significant result of the government's educational policy was a 2.6-fold increase in the number of students during the period from 1990 to $2000 \mathrm{~s}$, namely, from 2.8 to 7.4 million. The boom in the growth of demand for education was caused by households, which were driven by growth in wages, as well as a structural shift of the economy towards the services sector, the creation of new jobs, by the institutional changes that contributed to the growth in the number of educational institutions, including private ones, and admission of students for a paid education. The main thing was that the system has become more flexible, which allowed responding quickly to demand dynamics in the education sector [19]. The opportunities that have emerged in the transition period on both the demand and the supply side have become a major factor in the development of education.

In the new reality, the resource base can no longer ensure economic growth. The government should create a favorable institutional environment for human capital development by changing funding priorities towards education, and reviewing the principles of education management, increasing investment demand that creates jobs, as well as demand for educational services.

\section{Conclusion}

By definition, a project is a temporary enterprise designed to create unique products, services, or results. As the project implementation conditions become more complex, i.e. increasing project duration, funds, performers, etc., a problem arises concerning managing changes throughout the entire project structure.

The megaproject management and results depend on the impact of many factors. In contrast to technical projects, for projects implemented in the socio-economic sphere, the most important factor is the institutional environment. 
The effectiveness of Russian educational projects depends on the quality of the institutional environment.

Researchers need to pay particular attention to the methodological problems of developing and managing socio-economic projects in complex systems in the long term.

\section{References}

1. A.I. Lavagnon, International Journal of Project Management 36, 331-333 (2018)

2. P.M.L. Young Hoon Kwak, Challenges and Best Practices of Managing Government Projects and Programs to the Theory and Practices. 1, (2014).

3. K. Litsiou, Y. Polychronakis, A. Karami, K. Nikolopoulos, International Journal of Forecasting (2019)

4. G. Locatelli, G. Mariani, T. Sainati, M. Greco, International Journal of Project Management 35 252-268 (2017)

5. N. Sergeeva, C. Zanello, International Journal of Project Management 36(8), 1068-1081 (2018)

6. C. Biesenthal, S. Clegg, A. Mahalingam, S. Sankaran, International Journal of Project Management 36(1), 43-54 (2018).

7. G. Diethelm, Project Management (Bizness Pressa publishing house, St. Petersburg, 2004)

8. D. Lock, Fundamentals of Project Management (HIPPO, Moscow, 2004)

9. V.I. Voropaev, Project Management in Russia (Alans, Moscow, 1995)

10. G. Nuno, Megaproject Performance: Myth and Political Realities (Project Management Institute, 2017)

11. Y.J.-T. Zidane, A. Johansen, A. Ekambaram, Megaprojects - Challenges and Lessons Learned, 26th IPMA (International Project Management Association), Crete, Greece (2012)

12. "How rich is Russia?" Assessment of Russia's total well-being in the period from 2000 to 2017, (World Bank in the Russian Federation, 2019) Available at: https://www.vsemirnyjbank.org/en/country/russia/publication/how-wealthy-is-russia

13. Passport of the "Education" national project Available at: http://government.ru/info/35566/

14. K.L. Zhalalovna, S.E. Shishov, T.M. Rozhnova, K.S. Rozhnova, I.V. Polozhentseva, Universidad y Sociedad 12(2), 380-384 (2020)

15. Analytical report on the implementation of the federal budget and budgets of state extrabudgetary funds of the Russian Federation for January - December 2019, Accounts Chamber of the Russian Federation. Available at: http://audit.gov.ru/promo/analyticalreport-federal-budget-2019-4/index.html

16. Annual information on the implementation of the federal budget, Ministry of Finance of the Russian Federation. Available at: https://www.minfin.ru/ru/statistics/fedbud/execute/

17. A. Batanov, Accreditation in education 8(116) 15-16 (2019)

18. A challenge for the Ministry of Finance, Russian Newspaper Federal Issue 176(7934), (2019) Available at: https://rg.ru/2019/08/11/v-gd-vnesen-zakonoproekt-o-novomraschete-zarplat-dlia-vrachej-i-uchitelej.html

19. V. Gimpelson, R. Kapelyushnikov, Vedomosti 4410, 2 (2017) 